\title{
Bartłomiej SECLER
}

Uniwersytet im. Adama Mickiewicza w Poznaniu

\section{Sejmowe komisje Śledcze w systemie politycznym RP. Bilans dotychczasowych doświadczeń}

\section{Wprowadzenie}

$\mathcal{J}$ edną z zasadniczych funkcji parlamentu jest funkcja kontrolna. Jak zauważa Bogusław Banaszak, w nauce prawa konstytucyjnego wskazuje się często na różnice między węższym i szerszym pojęciem kontroli parlamentarnej (Banaszak, 2008, s. 113). W ujęciu węższym kontrola ta sprowadza się zarówno do analizy rzeczywistych działań władzy wykonawczej, jak i oceny ich efektywności i legalności. Natomiast drugie ujęcie adresowane jest do jednostek kontrolowanych przy jednoczesnym formułowaniu postulatów mających na celu korygowanie ich przyszłych działań (Banaszak, 2008, s. 113). O zakresie i formie wypełniania przez parlament funkcji kontrolnej decyduje w dużym stopniu system rządów. Należy mieć na uwadze, iż kontrola ta warunkowana jest systemem wzajemnych powiązań między organami państwa, które sprawują określone funkcje w ramach poszczególnych władz. Zdaniem Marii Kruk ,im dalej idąca specjalizacja i rozdzielanie ich funkcji, jak np. w przypadku systemu prezydenckiego, opartego na dość rygorystycznym podziale władz [...], tym bardziej ciężar kontroli przenosi się wprost na suwerena, który bezpośrednio powołuje władzę wykonawczą i bezpośrednio ją kontroluje" (Kruk, 2008, s. 9). Z kolei w systemie parlamentarnym, jak również systemach pochodnych - np. kanclerskim - czy mieszanych, zasadnicze mechanizmy ich funkcjonowania stają się, jak pisze M. Kruk, ,samoistnymi źródłami funkcji kontrolnej parlamentu, skierowanej na działalność rządu i administracji rządowej" (Kruk, 2008, s. 10).

Konstytucja RP z 1997 r. powierzyła wykonywanie funkcji kontrolnej Sejmowi RP. Art. 95 ust. 2 stanowi, że to właśnie Sejm sprawuje kontrolę nad działalnością Rady Ministrów w zakresie określonym przepisami ustawy zasadniczej i innych ustaw. Wśród najważniejszych form kontroli sejmowej należy wskazać: wotum nieufności wobec Rady Ministrów lub poszczególnych ministrów, interpelacje i zapytania poselskie, kontrola 
wykonania przez rząd budżetu państwa, kontrola wykonywana przez komisje sejmowe (Słomka, 2007, s. 1217).

Komisje sejmowe jako wyspecjalizowane wewnętrzne organy izby niższej parlamentu dzielimy na stałe i nadzwyczajne. Pierwszą grupę stanowią organy powołane na mocy Regulaminu Sejmu i funkcjonujące przez całą kadencję izby. Z kolei komisje nadzwyczajne tworzone są ad hoc celem rozpatrzenia konkretnej sprawy. Szczególnym rodzajem komisji nadzwyczajnych jest komisja śledcza (Słomka, 2007, s. 1213). Jako instrument kontrolny Sejmu, czerpie ona swój status prawny bezpośrednio z Konstytucji RP. Art. 111 ust. 1 stanowi, że Sejm może powołać komisję śledczą do zbadania określonej sprawy, zaś ust. 2, że tryb działania takiego organu określa ustawa. W 1999 r. Sejm uchwalił ustawę o sejmowej komisji śledczej, która została znowelizowana w 2005 r. (Ustawa z 21 stycznia 1999 r. o sejmowej komisji śledczej). Należy również podkreślić, iż zakres działania komisji śledczej precyzuje uchwała Sejmu o jej powołaniu, która reguluje szczegółowe zasady działania komisji, a także termin złożenia przez nią sprawozdania ze swojej pracy. W postępowaniu przed sejmową komisją stosuje się dodatkowo określone przepisy Regulaminu Sejmu (Uchwała Sejmu RP z 30 lipca 1992 r. - Regulamin Sejmu Rzeczypospolitej Polskiej; Uchwała Sejmu RP z 6 maja 2005 r. w sprawie zmiany Regulaminu Sejmu Rzeczypospolitej Polskiej) oraz Kodeksu postępowania karnego (Ustawa z 6 czerwca 1997 r. - Kodeks postępowania karnego).

Podstawowym celem niniejszego artykułu jest próba podsumowania dotychczasowych doświadczeń związanych z funkcjonowaniem sejmowych komisji śledczych powołanych na mocy ustawy Sejmu z 1999 r. Ich kilkuletnia aktywność skłania do wyakcentowania zagadnień, które wpływały lub w dalszym ciagu wpływają na niedostateczną skuteczność komisji śledczych. Z jednej strony należy bowiem zwrócić uwagę na szereg niedoskonałych regulacji prawnych przekładających się bezpośrednio na prace komisji, z drugiej zaś - iż większość powołanych komisji szybko stała się instrumentem walki politycznej i forum kreowania wizerunku konkretnych polityków, czy ugrupowań przez nich reprezentowanych.

Warto w tym miejscu podkreślić, że tradycje powoływania komisji sięgają w Polsce XVII w. B. Banaszak zauważa, że „niektóre komisje, zwłaszcza wyposażone w kompetencje kontrolne, dysponowały uprawnieniami śledczymi, włącznie z prawem wglądu w dokumenty i prawem słuchania wyjaśnień. W praktyce jednak nie korzystały z nich efektywnie, co szczególnie uwidaczniało się w kontroli gospodarki finansowej prowa- 
dzonej przez podskarbich. Sejm korzystał też z powołania organu do przeprowadzenia własnej kontroli administrowania dobrami królewskimi. Byli nimi lustratorowie uznawani za odrębną komisję" (Banaszak, 2007, s. 54-55). Konstytucja marcowa z 1921 r. w art. 34 stanowiła, że Sejm może wyłaniać i naznaczać dla zbadania poszczególnych spraw nadzwyczajnych komisje z prawem przesłuchiwania zainteresowanych stron oraz wzywania świadków i rzeczoznawców. W konstytucji kwietniowej z 1935 r. nie było wzmianki o możliwości powołania komisji śledczej. Doraźne komisje „niestałe dla poszczególnych spraw” powoływano jednak w oparciu o regulamin Sejmu z 1935 r. W okresie Polskiej Rzeczypospolitej Ludowej nie było praktyki powoływania komisji nadzwyczajnych o uprawnieniach śledczych. Z kolei w Małej konstytucji z 1992 r. znalazł się zapis (art. 11): „Sejm może powołać komisję dla zbadania określonej sprawy z prawem przesłuchiwania w trybie Kodeksu postępowania karnego osób przez nią wezwanych". Dość wspomnieć, że nie został użyty termin komisja śledcza (Bagieńska-Masiota, 2010, s. 23-54).

Z racji obszerności podjętego problemu, skupię się tylko na niektórych - w moim przekonaniu - najistotniejszych aspektach z zakresu dotychczasowej działalności sejmowych komisji śledczych w Polsce. Inne problemy zasygnalizuję lub rozwinę w kolejnych artykułach.

\section{Sejmowe komisje śledcze - wybrane problemy}

Prace nad ustawą o sejmowej komisji śledczej rozpoczęły się w maju 1998 r., w trakcie prac III kadencji Sejmu. Była to inicjatywa grupy 65 posłów koalicji rządzącej i opozycji, którzy przy tworzeniu projektu ustawy wykorzystywali doświadczenia innych państw w zakresie funkcjonowania komisji śledczych. Autorzy komentarza do ustawy o sejmowej komisji śledczej podkreślają że w jakimś stopniu było to związane z przygotowaniem Polski do akcesji do Unii Europejskiej i zbliżaniem systemów prawnych państw członkowskich. $Z$ drugiej zaś strony, przedłożony projekt nie miał charakteru dostosowawczego, ,bowiem jego materia, formalnie rzec biorąc, pozostawała poza sferą regulacji objętej prawem wspólnotowym. Chodziło raczej o wytworzenie podobnych standardów demokratycznych w zakresie sprawowanej przez parlament funkcji kontrolnej. W tym okresie w zdecydowanej większości parlamentów państw Unii Europejskiej działały komisje śledcze, wykonując głównie zadania związane z kontrolą funkcjonowania władzy wykonawczej, choć ich zna- 
czenie nie było tak duże, jak to bywa w systemach prezydenckich - np. w Stanach Zjednoczonych" (Kowalski, Lewandowski, Osiński, 2006, s. 11-12; Banaszak, 2007, s. 25-58).

Pierwsze czytanie projektu ustawy o sejmowej komisji śledczej miało miejsce na forum Komisji Sprawiedliwości i Praw Człowieka w lipcu 1998 r., a następnie na posiedzeniu plenarnym Sejmu. W toku prac komisji wprowadzono w projekcie kilkanaście poprawek. Zdecydowano się na przykład zmniejszyć maksymalną liczbę posłów mogących zasiadać w komisji śledczej - z 21 do 11. Rozszerzono również zakres działania komisji tak, by mogła ona badać pod kątem prawnym orzeczenia i decyzje wydane przez organy władzy publicznej. Ponadto z projektu wykreślono zapis o powoływaniu „rzecznika komisji” (Kowalski, Lewandowski, Osiński, 2006, s. 13).

Przy drugim czytaniu projektu ustawy w październiku 1998 r. zgłoszono w sumie 15 poprawek, które ostatecznie zostały odrzucone. Także poprawki Senatu uchwalone w grudniu 1998 r., postulujące m.in. zwiększenie uprawnień marszałka Sejmu, czy badanie przez komisje zgodności z prawem orzeczeń sądowych - w większości zostały odrzucone przez Sejm. Posłowie uwzględnili jedynie kilka poprawek Senatu, które jednak nie zmieniały zasadniczo treści ustawy, a w konsekwencji wypracowanego w izbie niższej parlamentu kształtu sejmowej komisji śledczej. Ustawa uchwalona w 21 stycznia 1999 r. trafiła do podpisu Prezydenta RP. Aleksander Kwaśniewski złożył w lutym 1999 r. wniosek do Trybunału Konstytucyjnego w sprawie zgodności z Konstytucją RP kilku zapisów ustawowych (wniosek Prezydenta RP złożony w trybie art. 122 ust. 3 Konstytucji RP dotyczył stwierdzenia nieważności następujących przepisów: art. 1 ust. 3 ustawy o sejmowej komisji śledczej z art. 2 oraz art. 111 Konstytucji RP; art. 8 ust. 1 ustawy o sejmowej komisji śledczej z art. 10 oraz art. 178 ust. 1 Konstytucji RP). Prezydent zwracał uwagę, że część artykułów ustawy jest sprzeczna z konstytucyjną zasadą demokratycznego państwa prawnego oraz z konstytucyjnymi zasadami trójpodziału i równowagi władz, a także niezawisłości sędziowskiej. Trybunał Konstytucyjny nie podzielił zastrzeżeń Prezydenta i w wydanym orzeczeniu uznał, że zaskarżone przepisy są zgodne z Konstytucją RP (Wyrok Trybunału Konstytucyjnego z 14 kwietnia 1999 r.).

W trakcie trzech minionych kadencji Sejmu RP (IV kadencja: 2001-2005; V kadencja: 2005-2007; VI kadencja: 2007-2011) powstało w sumie osiem komisji śledczych. W IV kadencji Sejmu powołano następujące komisje: 
- komisję śledczą do zbadania ujawnionych w mediach zarzutów dotyczących przypadków korupcji podczas prac nad nowelizacją ustawy o radiofonii i telewizji (powołana uchwałą Sejmu RP z 10 stycznia 2003 r.; swoją działalność zakończyła 24 września 2004 r.);

- komisję śledczą do zbadania zarzutu nieprawidłowości w nadzorze Ministerstwa Skarbu Państwa nad przedstawicielami Skarbu Państwa w spółce PKN Orlen S.A. oraz zarzutu wykorzystania służb specjalnych (d. UOP) do nielegalnych nacisków na organa wymiaru sprawiedliwości w celu uzyskania postanowień służących do wywierania presji na członków Zarządu PKN Orlen S.A. (powołana uchwałą Sejmu RP z 28 maja 2004 r.);

- komisję śledczą do zbadania prawidłowości prywatyzacji Powszechnego Zakładu Ubezpieczeń Spółka Akcyjna (powołana uchwałą Sejmu RP z 7 stycznia 2005 r.).

W V kadencji Sejmu powołano komisję śledczą do zbadania nieprawidłowości w działaniach organów Państwa w procesie przekształceń niektórych banków (powołana uchwałą Sejmu z 24 marca 2006 r.). Do 23 marca 2007 r. funkcjonowała ona pod nazwą: komisja śledcza do zbadania rozstrzygnięć dotyczących przekształceń kapitałowych i własnościowych w sektorze bankowym oraz działań organów nadzoru bankowego w okresie od 4 czerwca 1989 r. do 19 marca 2006 r.

W VI kadencji Sejmu powołano:

- komisję śledczą do zbadania okoliczności tragicznej śmierci byłej posłanki Barbary Blidy (powołana uchwałą Sejmu RP z 19 grudnia 2007 r.);

- komisję śledczą do zbadania sprawy zarzutu nielegalnego wywierania wpływu przez członków Rady Ministrów, Komendanta Głównego Policji, Szefa Centralnego Biura Antykorupcyjnego oraz Szefa Agencji Bezpieczeństwa Wewnętrznego na funkcjonariuszy Policji, Centralnego Biura Antykorupcyjnego oraz Agencji Bezpieczeństwa Wewnętrznego, prokuratorów i osoby pełniące funkcje w organach wymiaru sprawiedliwości w celu wymuszenia przekroczenia uprawnień lub niedopełnienia obowiązków w związku z postępowaniami karnymi oraz czynnościami operacyjno-rozpoznawczymi w sprawach z udziałem lub przeciwko członkom Rady Ministrów, posłom na Sejm Rzeczypospolitej Polskiej i dziennikarzom, w okresie od 31 października 2005 roku do 16 listopada 2007 roku (powołana uchwałą Sejmu RP z 11 stycznia 2008 r.);

- komisję śledczą do zbadania prawidłowości działań organów administracji rządowej w sprawie postępowań karnych związanych z uprowa- 
dzeniem i zabójstwem Krzysztofa Olewnika (powołana uchwałą Sejmu RP z 13 lutego 2009 r.);

- komisję śledczą do zbadania sprawy przebiegu procesu legislacyjnego ustaw nowelizujących ustawę z dnia 29 lipca 1992 r. o grach i zakładach wzajemnych i wydanych na ich podstawie przepisów wykonawczych w zakresie dotyczącym gier na automatach o niskich wygranych i wideoloterii oraz do zbadania legalności działania organów administracji rządowej badających ten proces (powołana uchwałą Sejmu RP z 4 listopada 2009 r. ${ }^{1}$ ).

Szczegółowa analiza prac poszczególnych, wyżej wymienionych komisji śledczych - przede wszystkim tych powołanych w IV i V kadencji Sejmu - pozwala na stwierdzenie, iż ustawa o sejmowej komisji śledczej z 1999 r. posiadała szereg niedoskonałych regulacji prawnych, co przekładało się bezpośrednio na problemy związane ze sprawnym funkcjonowaniem tych organów sejmowych. Wady przyjętych rozwiązań prawych dostrzegali posłowie, szczególnie ci, którzy czynnie brali udział w pracach komisji. Po kilku miesiącach funkcjonowania pierwszej komisji śledczej pojawiły się inicjatywy zmierzające do nowelizacji ustawy z 1999 r. W maju 2003 r. grupa posłów klubu parlamentarnego Prawa i Sprawiedliwości zaproponowała zmiany mające na celu ustalenie nowych reguł wyboru członków sejmowej komisji śledczej. Podkreślano, iż należy odstąpić od zasady parytetu politycznego. Obowiązujące rozwiązania w tym zakresie nie sprzyjały sprawnemu i rzetelnemu wyjaśnianiu sprawy, gdyż forum komisji stało się przede wszystkim areną walki politycznej. Wśród innych, licznych poprawek zgłaszanych w toku prac legislacyjnych nad ustawą pojawiła się propozycja, by prace komisji śledczej mogły być kontynuowane po zmianie kadencji Sejmu.

Nad nowelizacją ustawy pracowały komisje Sprawiedliwości i Praw Człowieka oraz Ustawodawcza, które wraz z końcem IV kadencji Sejmu nie przygotowały sprawozdania, które byłoby podstawą do rozpatrzenia

1 Uchwała ta była dwukrotnie zmieniona przez Sejm. Zmiany dotyczyły art. 5 uchwały zobowiązującej komisję do złożenia sprawozdania ze swoich prac w wyznaczonym terminie. Pierwotnie termin ten został wyznaczony na 28 lutego 2010 r. Już pierwsze tygodnie funkcjonowania komisji pokazały, iż nie uda się jej zakończyć prac w określonym przez Sejm terminie. W uchwale z 19 lutego 2010 r. art. 5 otrzymał brzmienie: „Komisja jest obowiązana do złożenia sprawozdania w terminie do dnia 30 kwietnia 2010 r." Natomiast 29 kwietnia 2010 r. Sejm po raz kolejny zmienił stosowną uchwałą termin zakończenia prac na 30 września 2010 r. 
przygotowanych poprawek przez izbę niższą parlamentu (Kowalski, Lewandowski, Osiński, 2006, s. 61).

Do sprawy nowelizacji ustawy o sejmowej komisji śledczej powrócono w kolejnej kadencji Sejmu. W lipcu 2004 r. stosowny wniosek złożyli posłowie klubu parlamentarnego Sojuszu Lewicy Demokratycznej. Ponadto, zaproponowano także zmiany w Regulaminie Sejmu polegające na dodaniu rozdziału na temat sejmowej komisji śledczej, który precyzować miał szereg kwestii związanych z jej funkcjonowaniem. Prace legislacyjne nad tymi projektami trwały kilka miesięcy i 3 czerwca 2005 r. nowelizacja ustawy została uchwalona przez Sejm (Kowalski, Lewandowski, Osiński, 2006, s. 62). Niewątpliwie, przyjęte zmiany usprawniły działalność kolejnych komisji śledczych, choć - na co zwrócę jeszcze uwagę w dalszej części tekstu - nie rozwiązały ostatecznie wszystkich problemów.

Ustawa w obecnym kształcie doprecyzowuje wiele regulacji prawnych, które przed nowelizacją były niejednokrotnie zarzewiem konfliktów i sporów nie tylko pomiędzy posłami zasiadającymi w kolejnych komisjach śledczych, ale także ekspertami komisji czy konstytucjonalistami.

Warto zwrócić uwagę, że zarówno Konstytucja RP, jak i ustawa o sejmowej komisji śledczej nie określa wyraźnie rodzajów spraw należących do właściwości komisji śledczych. Jak zauważa jednak Monika Zbrojewska ,przedmiotem postępowania komisji śledczej powinny być takie zdarzenia, które na etapie wstępnego postępowania in rem mogą uzasadniać hipotezę przyszłej odpowiedzialności karnej lub konstytucyjnej określonego kręgu osób podlegających jurysdykcji Trybunału Stanu albo posłów lub senatorów pod kątem ewentualnego uchylenia przysługującego im immunitetu formalnoprawnego. Poza zakresem postępowania przed komisją śledczą powinny pozostawać czyny osób (np. pospolitych przestępców) współdziałających z osobami, które ponoszą odpowiedzialność wyłącznie przed Trybunałem Stanu" (Zbrojewska, 2006, s. 26-27). Art. 7 ust. 2 ustawy o sejmowej komisji śledczej stanowi, że „komisja jest związana zakresem przedmiotowym określonym w uchwale o jej powołaniu”. W komentarzu do ustawy czytamy, iż ,zakres podmiotowy” jest to de facto „określona sprawa” zapisana w art. 1 ust. 2. Zdaniem autorów komentarza legalność funkcjonowania komisji nie zależy wyłącznie od niej, ale i od Sejmu, gdyż podjęta przez izbę uchwała określająca zakres badania przez komisję danej sprawy, powinna być zgodna z porządkiem konstytucyjnym państwa (Kowalski, Lewandowski, Osiński, 2006, s. 71). Ponadto, niejednokrotnie przypomina się, iż badana przez komisję sprawa 
nie może wykraczać poza ramy kontrolnej funkcji Sejmu, zaś sama komisja - jako organ izby - nie może posiadać więcej praw niż Sejm (Kowalski, Lewandowski, Osiński, 2006, s. 71). Podobne stanowisko zajął Trybunał Konstytucyjny, który we wspomnianym już orzeczeniu z 14 kwietnia 1999 r. (sygn. K. 8/99) uznał, że „kontrola parlamentarna oznacza prawo legislatywy do uzyskiwania informacji o działalności określonych organów i instytucji publicznych oraz prawo wyrażania oceny tej działalności. W doktrynie prawa konstytucyjnego podkreśla się, że funkcja kontrolna stanowi niezbędny atrybut parlamentu w państwie demokratycznym. W sprawowaniu tej funkcji przez parlament doktryna prawa konstytucyjnego widzi działalność zastępującą działania samego Narodu jako podmiotu władzy politycznej. Celem kontroli parlamentarnej jest zapewnienie funkcjonowania aparatu państwa zgodnie z interesem Narodu". W przytoczonym fragmencie wyroku, Trybunał Konstytucyjny odwołuje się do refleksji naukowej Pawła Sarneckiego (1997, s. 47).

Art. 136a Regulaminu Sejmu stanowi, że projekt uchwały w sprawie powołania komisji śledczej może być wniesiony przez Prezydium Sejmu lub co najmniej 46 posłów. Projekt taki powinien zawierać uzasadnienie wskazujące potrzebę i cel powołania komisji. Dotychczasowe doświadczenia w zakresie powoływania poszczególnych komisji śledczych pokazują, iż wyartykułowanie zarówno potrzeby, jak i celu powołania danej komisji, wzbudzało zawsze szereg kontrowersji i było przedmiotem sporu pomiędzy klubami parlamentarnymi, które niejednokrotnie zgłaszały różne projekty uchwały dotyczącej powołania jednej komisji. Po wybuchu tzw. ,afery hazardowej” z pomysłem (projektem uchwały) powołania komisji śledczej wystąpiły trzy kluby parlamentarne - Platformy Obywatelskiej, Prawa i Sprawiedliwości oraz Lewicy. Swojego projektu nie zgłosił jedynie klub Polskiego Stronnictwa Ludowego. Zgłoszone projekty istotnie różniły się od siebie. Spór parlamentarny o „komisję hazardową” dotyczył przede wszystkim zakresu jej prac, cezury czasowej obejmującej prowadzone postępowanie oraz to, który z klubów obsadzi stanowisko szefa komisji. Platforma Obywatelska uzasadniała powołanie komisji w następujący sposób: „Jesteśmy przekonani, że dogłębne zbadanie procesu legislacyjnego sięgające co najmniej roku 2002 oraz wcześniejszego ustawodawstwa, pozwoli nam poznać mechanizmy powstawania patologii w trakcie procesu legislacyjnego. Jesteśmy zdeterminowani, aby proces badania styku polityków i przedsiębiorców hazardowych przeprowadzić do końca i w każdym najdrobniejszym nawet, a ważnym dla wyciągnięcia odpowiednich wniosków na przyszłość, szczególe" (TVN24, 2010). Klub 
parlamentarny Prawa i Sprawiedliwości podkreślał m.in., iż „,W sprawę mogą być uwikłani Prezes Rady Ministrów, członkowie Rady Ministrów oraz inni wysocy urzędnicy państwowi. W związku z tym, iż niektórzy z nich sprawują nadzór nad organami ścigania, powołanie sejmowej komisji śledczej jest konieczne” (TVN24, 2010). Z kolei klub Lewicy zwracał uwagę, że „w interesie uczciwości politycznej jest powołanie sejmowej komisji śledczej dla wyjaśnienia wszystkich okoliczności tej sprawy" (TVN24, 2010).

W kontekście powyższego wątku warto odnotować, że obligatoryjność dodania uzasadnienia do projektu uchwały ma na celu przejrzystość w procesie powoływania komisji śledczej. „Brak takiego uzasadnia stanowi wadę formalną projektu i prowadzić musi do nienadania projektowi biegu przez marszałka Sejmu. Wydaje się, że w takiej sytuacji marszałek Sejmu powinien wykazać braki wnioskodawcom, wzywając do ich usunięcia, a wnioskodawcy, po uczynieniu tego, projekt powinni wnieść ponownie" - czytamy w komentarzu do przepisów Regulaminu Sejmu (Kowalski, Lewandowski, Osiński, 2006, s. 232).

Powołanie sejmowej komisji śledczej wymaga zgody bezwzględnej większości posłów. Ustawa stanowi, że w skład komisji może wchodzić maksymalnie 11 członków ${ }^{2}$, zaś jej skład powinien odzwierciedlać - odpowiednio do jej liczebności - sejmową reprezentację klubów i kół poselskich, które mają swoich przedstawicieli w Konwencie Seniorów. Ustawa określa także warunki, które musi spełniać poseł kandydujący na członka komisji. Osoba taka nie może być związana w jakikolwiek sposób ze sprawą (Ustawa z 21 stycznia 1999 r. o sejmowej komisji śledczej, art. 4) ${ }^{3}$. Wielokrotnie zdarzało się, iż przy próbie wyłączenia ze składu danego członka komisji, powoływano się w uzasadnieniu wniosku na związek osoby ze sprawą, czego konsekwencją jest jego brak bezstronności.

W grudniu 2009 r. „komisja hazardowa” podjęła decyzję o wyłączeniu ze składu osobowego posłanki Beaty Kempy i posła Zbigniewa Wasser-

2 W trzech pierwszych komisjach śledczych (IV kadencja Sejmu) zasiadało po 10 posłów. Po wyborach w 2005 i 2007 roku utworzone zostały w Sejmie cztery kluby parlamentarne, co przełożyło się także na liczbę posłów (składy 7-osobowe) w poszczególnych komisjach śledczych.

${ }^{3} \mathrm{O}$ wyłączeniu ze składu komisji stanowi art. 5 ustawy. Natomiast w art. 6 czytamy: ,Jeżeli w trakcie postępowania prowadzonego przez komisję zostanie ujawniona okoliczność, która mogłaby wywołać wątpliwości co do bezstronności członka komisji przy wykonywaniu czynności przesłuchania osoby wezwanej przez komisję, ulega on wyłączeniu z tej czynności na wniosek osoby wezwanej lub członka komisji”". 
mana z klubu parlamentarnego Prawa i Sprawiedliwości. Wniosek w tej sprawie złożyli posłowie Platformy Obywatelskiej Sławomir Neumann i Jarosław Urbaniak, którzy argumentowali, że posłowie PiS muszą zostać przesłuchani przez komisję, gdyż w 2007 r. jako przedstawiciele rządu Jarosława Kaczyńskiego, składali uwagi do projektu zmian o ustawie hazardowej ${ }^{4}$. Na początku stycznia 2010 r., już po przesłuchaniu wyżej wymienionych posłów, klub Prawa i Sprawiedliwości ponownie zgłosił ich kandydatury do „komisji hazardowej”. W sejmowym głosowaniu posłowie Platformy Obywatelskiej wstrzymali się od głosu podczas głosowania nad B. Kempa, natomiast 193 z nich głosowało przeciwko powrotowi Z. Wassermana. Posłowie Polskiego Stronnictwa Ludowego w obu przypadkach poparli opozycję. Ostatecznie posłowie zostali przywróceni do komisji śledczej ${ }^{5}$.

W dalszej części znowelizowana ustawa o sejmowej komisji śledczej reguluje m.in. kwestie dotyczące praw i obowiązków osób wezwanych przed komisję, czy możliwości wystapienia przez komisję z wnioskiem o pociagnięcie do odpowiedzialności konstytucyjnej przed Trybunałem Stanu osób, co do których zachodzi podejrzenie, że w sposób zawiniony, w zakresie swojego urzędowania, popełniły czyn naruszający Konstytucję lub ustawę. Stanowi o tym art. 18 ust. 1 ustawy. Wniosek taki wymaga zgody $2 / 3$ członków komisji w obecności co najmniej połowy jej składu. Warto odnotować, iż w dotychczasowej praktyce funkcjonowania komisji śledczych po 1999 r. nie skorzystały one z takiej możliwości. Nie oznacza to jednak, że poszczególni członkowie komisji śledczych nie wyrażali publicznie przekonania, iż w stosunku do określonych osób wniosek taki powinien być postawiony. W kwietniu 2010 r. pojawiły się w mediach informacje, iż wniosek o postawienie byłego ministra sprawiedliwości Zbigniewa Ziobro ${ }^{6}$ przed Trybunałem Stanu ma znaleźć się w przygotowywanym przez posłów Platformy Obywatelskiej cząstkowym raporcie z prac „naciskowej komisji śledczej”. Zwolennikiem takiego wniosku był

415 grudnia 2009 r. komisja podjęła decyzję w sprawie wezwania w charakterze świadków posłów: Beatę Kempę i Zbigniewa Wassermana.

5 Kandydatury posłów PiS głosowane były osobno. Za powrotem B. Kempy do komisji głosowało 235 posłów, 26 było przeciw, 176 wstrzymało się od głosu. Za Z. Wassermanem opowiedziało się 230 posłów, 193 było przeciw, a 14 wstrzymało się od głosu.

W 2004 r. w przygotowanym przez Z. Ziobro raporcie końcowym z prac komisji ds. ,,afery Rywina”, postulowano postawienie przed Trybunałem Stanu m.in. prezydenta A. Kwaśniewskiego i premiera L. Millera. 
poseł Robert Węgrzyn. Przewodniczący komisji Andrzej Czuma zdystansował się jednak od takiego pomysłu. „Ani Platforma, ani komisja śledcza nie rozważają takiej opcji. To są luźne uwagi posła Węgrzyna. Jestem odpowiedzialny za przygotowanie sprawozdania z prac komisji i nic takiego nie przewiduję" - skomentował dla TVP Info A. Czuma (TVP Info, 2010).

Zgodnie z art. 19a ustawy o sejmowej komisji śledczej, komisja sporządza sprawozdanie ze swojej działalności ${ }^{7}$. Należy odnotować, iż dotychczas tylko komisja do zbadania ujawnionych w mediach zarzutów dotyczących przypadków korupcji podczas prac nad nowelizacją ustawy o radiofonii i telewizji, formalnie zakończyła swoją pracę, przygotowując końcowy raport. Nie obyło się jednak przy tym bez sporu politycznego. Istniały bowiem różne wersje raportu. W kwietniu 2004 r. komisja przyjęła sprawozdanie, do którego następnie zgłoszone zostały wnioski mniejszości (Szmyt, 2008, s. 157). Akceptację, wbrew woli przewodniczącego i kilku innych członków komisji uzyskał raport autorstwa Anity Błochowiak z Sojuszu Lewicy Demokratycznej. Ostatecznie, oprócz sprawozdania posłanki lewicy, przygotowane zostały mniejszościowe wersje raportu. W maju 2004 r. Sejm niespodziewanie opowiedział się za najradykalniejszym ze sprawozdań przygotowanym przez Zbigniewa Ziobro.

Zamieszanie związane z raportami z prac komisji ds. ,,afery Rywina” - każde z przygotowanych sprawozdań zawierało inne wnioski i ustalenia - obnażyło nieprecyzyjność pierwotnej ustawy. Po pierwsze dlatego, że nie przewidywała ona w jakiej kolejności wnioski powinny być głosowane. Po drugie, ustawa nie określała formalno-prawnego statusu tych sprawozdań. Po trzecie zaś, co podkreślano w licznych komentarzach debata nad sprawozdaniem z prac komisji jest de facto dyskusją nad prawdziwością konkretnych zadań, do których wyjaśnienia komisja została powołana. Warto podkreślić, iż przepisy z 2005 r. uporządkowały postępowanie w tym zakresie. Sprawozdanie komisji śledczej może bowiem zawierać zdania odrębne posłów, którzy są członkami danej komisji. Zdanie odrębne może zawierać odrębne stanowisko zarówno co do całości, jak również części stanowiska komisji. Do sprawozdania - w trakcie jego rozpatrywania przez Sejm - nie ma możliwości zgłaszania poprawek. Nad sprawozdaniem komisji śledczej Sejm nie przeprowadza głosowania.

7 Przekazanie Marszałkowi Sejmu sprawozdania z działalności komisji śledczej świadczy o jej wyjaśniającym charakterze. Warto podkreślić, iż ustalenia zawarte w raporcie końcowym nie są dla organów państwa w żaden sposób wiążące. 
Znowelizowana ustawa o sejmowej komisji śledczej stanowi w art. 21, iż w przypadku nierozpatrzenia przez Sejm sprawozdania z działalności komisji przed upływam kadencji, może być ono przedmiotem debaty w Sejmie następnej kadencji. Możliwości takiej nie gwarantowała pierwotna wersja ustawy z 1999 r. Inaczej wygląda również sprawa postępowania prowadzonego przez komisję, gdyż obowiązuje - wyrażona w art. 20 ustawy - zasada dyskontynuacji prac komisji śledczej ze względu na upływ kadencji Sejmu - postępowanie ulega zamknięciu, a czynności zlecone lub wnioskowane przez komisję automatycznie się kończą. „Ustawodawca stanął na stanowisku, że ekonomika postępowania w tym przypadku powinna znaleźć pierwszeństwo przed zasadą, że komisja śledcza jest emanacją Sejmu danej kadencji (jako jego organ). Ustawodawca uznał najwyraźniej, że sytuacja, w której komisja zakończyła swoją pracę, składając na ręce marszałka Sejmu sprawozdanie ze swej działalności, a Sejmowi danej kadencji zabrakło czasu na rozpatrzenie tegoż sprawozdania, nie powinna skutkować zaprzepaszczeniem dorobku danej komisji. Oczywiście nierozpatrzenie takiego sprawozdania nie wykluczałoby możliwości powołania przez Sejm przyszłej kadencji nowej komisji śledczej w tożsamej sprawie, która to komisja mogłaby nawet przejąć całość materiałów swojej poprzedniczki, uznając jej dorobek, niemniej jednak przeczyłoby to zasadzie ekonomiki postępowania parlamentarnego" - podkreślają autorzy komentarza do ustawy o sejmowej komisji śledczej (Kowalski, Lewandowski, Osiński, 2006, s. 226).

Specyfiką polskich komisji śledczych jest prowadzenie postępowania na posiedzeniach jawnych. Odstępstwo od tej zasady szczegółowo reguluje art. 11h ustawy (posiedzenia zamknięte) oraz odpowiednie przepisy Regulaminu Sejmu i Kodeksu postępowania karnego. Art. 11i ustawy o sejmowej komisji śledczej stanowi, iż „do postępowania w sprawach wzywania oraz przesłuchiwania osób wezwanych przez komisję oraz zwalniania ich z obowiązku zachowania tajemnicy w zakresie nieuregulowanym w niniejszej ustawie [art. 11e ustawy - zwolnienie z tajemnicy państwowej; art. 11f - tajemnica inna niż państwowa; art. $11 \mathrm{~g}$ - tajemnica adwokacka, notarialna, lekarska - przyp. B.S.] stosuje się odpowiednie przepisy Kodeksu postępowania karnego dotyczące w tym zakresie świadków" (Ustawa z 21 stycznia 1999 r. o sejmowej komisji śledczej).

Od czasu powołania pierwszej sejmowej komisji śledczej pojawia się szereg problemów związanych przede wszystkim z interpretacją poszczególnych przepisów, czego konsekwencją jest nie tylko częste spowalnianie prac komisji, ale również - na co kilkakrotnie zwracałem już uwagę 
- zaostrzenie rywalizacji politycznej. Wspomniane rozbieżności interpretacyjne występują zarówno pomiędzy członkami poszczególnych komisji, jak również jej ekspertami, którzy niejednokrotnie byli posądzani przez posłów komisji śledczych o stronniczość czy sprzyjanie określonej opcji politycznej przy wydawaniu opinii w określonej sprawie.

Analizując prace dotychczas powołanych sejmowych komisji śledczych można wskazać na wiele konkretnych problemów związanych z funkcjonowaniem poszczególnych komisji. W dużej mierze dotyczyły one i w dalszym ciagu dotyczą np. statusu świadka zeznającego przed komisją śledczą mimo że ustawa dość szczegółowo określa uprawnienia osoby wezwanej. W tym kontekście nie sposób nie zwrócić uwagi na problem wezwania i przesłuchania przed komisją śledczą osoby urzędującego Prezydenta RP. Badając dotychczasowe opinie, ekspertyzy, czy komentarze w tej sprawie można odnieść wrażenie, że problem nie doczekał się jednoznacznego rozstrzygnięcia. $Z$ jednej strony wyrażane jest przekonanie, że działalność komisji śledczej musi mieścić się w ramach konstytucyjnie określonej kontrolnej funkcji Sejmu, z drugiej zaś podkreśla się fakt, iż Kodeks postępowania karnego nie przewiduje żadnych przeszkód co do kwestii przesłuchania jako świadka jakiejkolwiek osoby sprawującej funkcję państwową, bądź piastującej określone stanowisko.

Monika Zbrojewska zauważa, iż ,,skoro ustawodawca w art. 11 ust. 1 ustawy o s.k.ś. posłużył się sformułowaniem »każda osoba«, to jednoznacznie wskazuje, że chodzi o każdego bez względu na zajmowaną funkcję, pełnione stanowisko czy wykonywany zawód. Absurdem byłoby wymagać od ustawodawcy, aby zaznaczył, że pod pojęciem »każdy« rozumie np. Prezydenta RP, prezesa Rady Ministrów, marszałka Sejmu, marszałka Senatu, prezesa NBP. Oczywiście, pozycja ustrojowa Prezydenta RP jest inna od »każdego«, chociażby z tego powodu, że w myśl art. 126 ust. 1 Konstytucji RP jest on najwyższym przedstawicielem RP i gwarantem ciagłości władzy państwowej. Natomiast, zgodnie z treścią art. 145 Konstytucji RP, za naruszenie konstytucji, ustawy lub za popełnienie przestępstwa może być pociagnięty do odpowiedzialności przed Trybunałem Stanu" (Zbrojewska, 2006, s. 29). W podobnym tonie wypowiada się Artur Kowalski, współautor komentarza do ustawy o sejmowej komisji śledczej: „[...] gdyby intencją ustawodawcy, w tym konstytucyjnego, było wyłączenie Prezydenta Rzeczypospolitej Polskiej z kręgu osób, które mogą być przesłuchane przez komisję śledczą, to stosowne przepisy zostałyby zamieszczone w konstytucji albo w ustawie o sejmowej komisji śledczej. Brak takiej regulacji wyraźnie wskazuje, że ustawodawca 
nie obejmował swoim zamiarem zwolnienia Prezydenta Rzeczypospolitej Polskiej z obowiązku składania zeznań przed sejmową komisją śledczą" (Kowalski, Lewandowski, Osiński, 2006, s. 145).

Z kolei Wojciech Sokolewicz zwraca uwagę, że Prezydent RP jako głowa państwa nie ponosi odpowiedzialności politycznej przed Sejmem. Izba nie może zatem ,uchwalić wotum nieufności dla prezydenta, nie może też stosować wobec niego innych środków kontroli, jak adresowanie doń wypowiedzi posłów (interpelacje, zapytania czy pytania w sprawach bieżących, o czym - niestety - posłowie niekiedy zapominają wbrew dyrektywie art. 115 konstytucji). Brak parlamentarnej odpowiedzialności politycznej stanowi tu refleks zakładanej neutralności głowy państwa, wobec bieżącej polityki, poza jej najbardziej doniosłymi, mającymi ogólnonarodowe znaczenie kierunkami, jak ochrona suwerenności oraz bezpieczeństwa zewnętrznego i wewnętrznego państwa, jego terytorium i granic, a także zapewnienie respektowania w życiu publicznym konstytucji, sprawowane zawsze za pomocą tych tylko instrumentów prawnych, które zostały przekazane prezydentowi przez prawo, to jest przez konstytucję i ustawy" (Sokolewicz, 2004, s. 70-71). W. Sokolewicz wyraża przekonanie, iż jeżeli prezydent wyrazi taką wolę może złożyć wyjaśnienia zarówno z własnej inicjatywy, jak również inicjatywy sejmowej komisji śledczej. Ponadto, do złożenia takich wyjaśnień prezydent nie jest zobowiązany i komisja nie może przymuszać głowy państwa do złożenia zeznań oraz karać go za odmowę ich złożenia. Wyjaśnienia prezydenta nie mogą dotyczyć jego własnych działań, gdyż te nie są objęte kontrolą parlamentarną, a jedynie wiedzy o zachowaniu innych podmiotów. Zdaniem W. Sokolewicza w przypadku zgody prezydenta na współpracę z komisją, powinna ona ,przyjąć określony modus procedenti, polegający na wcześniejszym przedstawieniu prezydentowi pytań na piśmie $\mathrm{z}$ ewentualną możliwością udzielenia dodatkowych wyjaśnień przewodniczącemu komisji (lub całemu jej prezydium) w siedzibie prezydenta" (Sokolewicz, 2004, s. 73).

W praktyce funkcjonowania sejmowych komisji śledczych z problemem wezwania urzędującego Prezydenta RP zetknęła się m.in. komisja do zbadania ujawnionych w mediach zarzutów dotyczących przypadków korupcji podczas prac nad nowelizacją ustawy o radiofonii i telewizji - wniosek taki złożyła posłanka Renata Beger. A. Kwaśniewski pytany przez dziennikarzy czy stawi się przed komisją odpowiedział: „Ja się mogę stawić. Mogę zaśpiewać i zatańczyć, tylko po co?”. Tłumaczył, że urzędująca głowa państwa nie może stawać przed komisją śledczą, która 
wypełniając swoje kompetencje wkracza w obszar władzy prezydenta, która nie podlega kontroli Sejmu.

Wniosek w sprawie wezwania prezydenta Kwaśniewskiego zgłosił także poseł Antoni Macierewicz, członek komisji do zbadania zarzutu nieprawidłowości w nadzorze Ministerstwa Skarbu Państwa nad przedstawicielami Skarbu Państwa w spółce PKN Orlen SA oraz zarzutu wykorzystania służb specjalnych do nielegalnych nacisków na organa wymiaru sprawiedliwości w celu uzyskania postanowień służących do wywierania presji na członków Zarządu PKN Orlen SA. Mimo że prezydent wstępnie wyrażał wolę spotkania z komisją, ostatecznie odmówił. Podczas konferencji prasowej podkreślał, że nie zamierza uczestniczyć w awanturze politycznej. Ponadto, zapowiedział, że nie weźmie udziału w żadnym z posiedzeń którejkolwiek z komisji śledczych, gdyż jako głowa państwa nie może być przesłuchiwany przez organ sejmowy.

Przed formalnym powołaniem tzw. ,komisji hazardowej” media informowały, że Platforma Obywatelska rozważa możliwość wezwania przed komisję prezydenta Lecha Kaczyńskiego. Według jednej z gazet, pretekstem do przesłuchania L. Kaczyńskiego mógłby być jego rzekomy lobbing $\mathrm{w}$ sprawie wideo-loterii w okresie kiedy sprawował funkcję ministra sprawiedliwości („Wprost”, 2010). Do wezwania prezydenta Kaczyńskiego nigdy jednak nie doszło.

Wśród innych problemów związanych z funkcjonowaniem ośmiu dotychczas powołanych sejmowych komisji śledczych znalazły się m.in.: problem przekroczenia przez komisję śledczą mandatu uzyskanego uchwałą Sejmu; problem przesłuchania prokuratora jako świadka przez komisję śledcza; tryb rozpatrywania przez Sejm sprawozdania komisji śledczej; problem udostępniania komisji śledczej informacji z zasobów Instytutu Pamięci Narodowej; problem wyłączenia członków komisji śledczej z czynności przesłuchania osoby wezwanej przez komisję; problem odwołania przez Sejm członków komisji śledczej; problem odmowy podpisania protokołu przez świadka składającego zeznania przed komisją śledcza; problem przeprowadzenia konfrontacji świadków zeznających przed komisją śledczą.

\section{Podsumowanie}

Istnienie oraz funkcjonowanie sejmowych komisji śledczych w Polsce budzi szereg kontrowersji. Pomijając problemy natury prawnej wynika- 
jące zarówno z niedoskonałości przepisów (przede wszystkim pierwotnej wersji ustawy o sejmowej komisji śledczej z 1999 r.), jak i nieznajomości prawa przez niektórych członków komisji śledczych, co zdecydowanie utrudnia sprawne procedowanie, należy zwrócić uwagę na powszechną krytykę prac komisji śledczych. Najpoważniejszym problemem wydaje się ich nadmierne upolitycznienie. W zasadzie wszystkie powołane komisje śledcze stały się - przy dużym udziale środków społecznego przekazu - areną ostrej rywalizacji politycznej. Niejednokrotnie przekłada się to na nieudolność postępowania oraz obstrukcję prac komisji. Warto zwrócić także uwagę na brak odpowiednich kompetencji wielu powoływanych do poszczególnych komisji osób czy kreowanie wizerunku osób w niej zasiadających (Żukiewicz, 2009). Niejednokrotnie, wiele do życzenia pozostawia język wypowiedzi członków komisji śledczych oraz świadków przed nią zeznających. W obliczu pomysłów na tworzenie kolejnych komisji śledczych (w VII kadencji Sejmu) warto zastanowić się nad zasadnością powoływania kolejnych zespołów, których prac de facto nic nie wynika. Przyjęte dotychczas raporty końcowe były szeroko krytykowane za niespójność, wewnętrzne sprzeczności, lakoniczne stwierdzenia. Społeczeństwo było zaś niejednokrotnie świadkiem kompromitujących elity polityczne spektakli, które w żaden sposób nie przyczyniały się do poprawy jakości i przejrzystości życia politycznego w Polsce.

Prof. Andrzej Zoll, który niedługo po katastrofie prezydenckiego samolotu pod Smoleńskiem apelował na łamach „Tygodnika Powszechnego" o umorzenie postępowań przed sejmowymi komisjami śledczymi, twierdzi - nie jest to głos odosobniony - że Sejm nie jest od prowadzenia śledztw. „Niech śledztwa prowadzi prokuratura, niech o winie orzekają sądy. [...] Komisje śledcze przerodziły się w areny najgorszych bijatyk politycznych i przy wykorzystaniu mediów często dochodzi do wielkiego napięcia o sprawy, które nie są rangi komisji śledczych powoływanych przez parlament. Skończmy ze sprawami nacisków politycznych i hazardu. Umórzmy aspekt polityczny tych spraw" - przekonuje A. Zoll (Zoll, 2010).

\section{Bibliografia}

Bagieńska-Masiota A. (2010), Sejmowa komisja śledcza w systemie politycznym Rzeczypospolitej Polskiej, Wydawnictwo Sejmowe, Warszawa. 
Banaszak B. (2007), Komisje śledcze we wspótczesnym parlamentaryzmie państw demokratycznych, Wydawnictwo Sejmowe, Warszawa.

Banaszak B. (2008), Sejmowa komisja śledcza jako forma sprawowania kontroli przez Sejm, ,Przegląd Sejmowy”, nr 3.

Konstytucja Rzeczypospolitej Polskiej z dnia 2 kwietnia 1997 r., Dz. U. 1997, Nr 78 poz. 483.

Kowalski A., Lewandowski M., Osiński T. (2006), Sejmowa komisja śledcza. Ustawa z 1999 r. z komentarzem, Wydawnictwo Sejmowe, Warszawa.

Kruk M. (2008), Funkcja kontrolna Sejmu RP, Wydawnictwo Sejmowe, Warszawa.

Sarnecki P. (1997), Funkcje i struktura parlamentu wedtug nowej Konstytucji, „Państwo i Prawo", nr 11-12.

Sokolewicz W. (2004), Opinia w sprawie możliwości przesłuchania Prezydenta RP przez sejmowa komisję śledcza, ,Przegląd Sejmowy”, nr 1.

Słomka T. (2007), Ustrój organów władzy państwowej w RP, w: Społeczeństwo i polityka. Podstawy nauk politycznych, red. K. A. Wojtaszczyk, W. Jakubowski, Wydawnictwo Aspra JR F.H.U, Warszawa.

Szmyt A. (2008), O sejmowych komisjach śledczych, w: A. Szmyt, Elementy praktyki sejmowej pod rzqdami Konstytucji RP (1997-2007), Wydawnictwo Gdańskiej Wyższej Szkoły Administracji, Gdańsk.

TVN24 (2010), Dziś batalia o szefa i zakres prac komisji hazardowej, http://www.tvn24.pl/ 12690,1625021,0,6,dzis-batalia-o-szefa-i-zakres-prac-komisji-hazardowej,wiadomosc.html, 29.05.2010.

TVP Info (2010), Ziobro przed Trybunat Stanu?, http://www.tvp.info/informacje/polska/ziobro-przed-trybunal-stanu/1635085, 30.05.2010.

Uchwała Sejmu RP z dnia 30 lipca 1992 r. - Regulamin Sejmu Rzeczypospolitej Polskiej, M.P. 2002, Nr 23, poz. 398, z późn. zm.

Uchwała Sejmu RP z dnia 6 maja 2005 r. w sprawie zmiany Regulaminu Sejmu RP, M.P. 2005, Nr 42, poz. 556.

Ustawa z dnia 6 czerwca 1997 r. - Kodeks postępowania karnego, Dz. U. 1997, Nr 89, poz. 555 , z późn. zm.

Ustawa z dnia 21 stycznia 1999 r. o sejmowej komisji śledczej, Dz. U. 1999, Nr 35, poz. 321, z późn. zm.

Wyrok Trybunatu Konstytucyjnego z 14 kwietnia 1999 r., sygn. K. 8/99.

Zbrojewska M. (2006), Wybrane karnoprocesowe zagadnienia postęowania przed sejmowa komisja śledcza, ,Przegląd Sejmowy”, nr 5.

Zoll A. (2010), Polski scenariusz, rozmowę przeprowadził Andrzej Brzeziecki, „Tygodnik Powszechny", nr 16.

Żukiewicz P. (2009), Liderzy polityczni w polskich komisjach śledczych, Dom Wydawniczy DUET, Toruń. 


\title{
Parliamentary commissions of inquiry in the political system of contemporary Poland. The experience so far
}

\begin{abstract}
Summary
The purpose of this paper is to reflect upon the experience related to the appointment and operations of parliamentary commissions of inquiry in Poland. The author ponders whether the commissions appointed so far have contributed to improving the quality of political life and provided reliable explanations of scandals in circles of power, or perhaps they have rather become an instrument of political struggle, allowing political rivals to be easily discredited. The analysis conducted indicates that, on account of the composition of commissions (including politicians), so far their main focus has been political rivalry, instead of the actual investigation of scandals. The author also has reservations about the ineffectiveness of commissions of inquiry, which stems from imperfect legal provisions. The considerations refer to the supervisory function of the Polish parliament.
\end{abstract}

